\title{
Grapevine nutritional status and $K$ concentration of must under future expected climatic conditions texturally different soils
}

\author{
Urtzi Leibar $^{1,2}$, Inmaculada Pascual ${ }^{3}$, Ana Aizpurua ${ }^{1}$, Fermín Morales $^{4}$, Olatz Unamunzaga ${ }^{\text {* }}$
}

${ }^{1}$ Neiker-Tecnalia, Environment Quality Department. Bizkaia Technological Park. 812. Berreaga St.1. E-48160, Derio, Bizkaia, Spain. ${ }^{2} H a z i$ Fundazioa, Area of Statistics, Sectorial Analysis and Paying Agency's Technical Services, Granja Modelo de Arkaute s/n, 01192, Arkaute, Araba, Spain. ${ }^{3}$ Universidad de Navarra, Plant Stress Physiology Group (Environmental Biology Department), Associated Unit to CSIC, EEAD, Zaragoza and ICVV, Logroño. Faculties of Sciences and Pharmacy, Irunlarrea 1, E-31008, Pamplona, Navarra, Spain. ${ }^{4}$ Department of Plant Nutrition, Aula Dei Experimental Station, CSIC, PO Box 13034, 50080 Zaragoza, Spain.

*Corresponding author: ounamunzaga@neiker.eus

\begin{abstract}
Nutrition is a relevant issue for winegrowers because it influences grapevine growth, berry composition, as well as must and wine quality. In this research, the following impacts on the nutritional status of cv. Tempranillo grapevines were evaluated: simulated 2100 expected $\mathrm{CO}_{2}$, temperature $(\mathrm{T})$ and relative humidity $(\mathrm{RH})$ conditions (FCC; $700 \mu \mathrm{mol} \mathrm{CO} / \mathrm{mol}$ air, $28 / 18^{\circ} \mathrm{C}$ day/night and 33/53\% RH, day/night) vs. current $\mathrm{CO}_{2}, \mathrm{~T}$ and $\mathrm{RH}$ conditions (Curr; $390 \mu \mathrm{mol} \mathrm{CO} / \mathrm{mol}$ air, $24 / 14^{\circ} \mathrm{C}$ and $45 / 65 \% \mathrm{RH}$ ); well-watered (WW) vs. future expected water deficit (WD); and three texturally different soils with different clay contents (41, 19 and 8\%). FCC resulted in reduced concentrations in leaf blades of $\mathrm{N}$ and $\mathrm{Ca}$ at veraison and $\mathrm{N}$ and $\mathrm{Zn}$ at full maturity. WD resulted in higher leaf blade $\mathrm{Na}$ and $\mathrm{Mn}$ concentrations at veraison and maturity, respectively compared to WW. However, $\mathrm{K}$ concentrations in the leaves and must were higher for WW than WD. Higher concentrations of $\mathrm{Ca}$ and $\mathrm{Mn}$ were found in leaf blades of grapevines sampled at full maturity from more clayey soils. Even when nutrient inputs exceeded plant extractions, high soil clay content increased the K concentration in must and consequently, could affect wine quality in terms of acidity loss. However, future expected water stress will have the opposite effect, reducing the berry K uptake under high soil clay (41\%) conditions.
\end{abstract}

Keywords: Climate change, leaf analysis, potassium, clay content, water deficit 


\section{Introduction}

Nutrition is an important issue for wine grape growers since it impacts grapevine growth, fruit set, crop yield, berry composition and ultimately the quality of the must and wine. Grapevine nutrient needs are moderate, but unbalanced fertilization may lead to both undesired effects on wine quality, including a lack of acidity in wines made from grapes with an excessive potassium (K) supply, and to environmental impacts as a consequence of groundwater nitrate contamination (Romero et al., 2010). Increasingly, consumers and legislators are demanding sustainable production practices with concomitant reduction in vineyard inputs and environmental impacts, putting pressure on winegrowers to better manage fertilizers. Plant analysis is a reliable method to assess grapevine nutritional status. Therefore, fertilizer recommendation programmes are very useful for fruit tree and vineyard management. However, there is still discussion about the most suitable sampling dates and the appropriate tissues to analyse (Benito et al., 2013). Despite the obvious influence of soil fertilization on plant growth and yield, knowledge and understanding about nutrient availability, the actual uptake of different fertilizers and how they are affecting grapevine physiology and productivity is surprisingly poor (Brataševec et al., 2013).

Monitored data and model simulations indicate that climatic conditions are changing, resulting in increased atmospheric $\mathrm{CO}_{2}$ concentrations, higher temperatures and rates of evaporation, changes in precipitation patterns, with greater seasonal variability, and more frequent extreme weather events (IPCC, 2013). Thus, the impacts of global warming at regional scales are raising many questions for wine producers. Regarding grapevine nutrition, changes in temperature and evaporation are likely to affect the availability of soil water for grapevines, as well as the internal mechanisms of water movement through the grape- vine, with consequences for nutrient uptake and mobilization (Proffitt and Campbell-Clause, 2012). Martins et al. (2014) reported that the influence of enhanced atmospheric $\mathrm{CO}_{2}$ concentrations on plant productivity and growth has often been explored in combination with alterations in photosynthesis, respiration and carbon use and allocation (Zhu et al., 2012), whereas corresponding modifications in mineral composition (with the exception of nitrogen) have received much less attention (Thiec et al., 1995). Heavier and more frequent rainfall events could increase the incidence of water logging, leaching and erosion, thereby causing unfavourable conditions for nutrient uptake, as well as a loss of nutrients from the soil (Proffitt and CampbellClause, 2012). This, in turn, is likely to directly affect the ability of grapevines to extract nutrients from the soil and, therefore, to modify nutrient mobility within the grapevine (Proffitt and Campbell-Clause, 2012). Potassium is by far the major cation related to berry ripeness (Mpelasoka et al., 2003), and its concentration in grapes is related to the must acidity. In a climate change scenario, this cation becomes very relevant since high temperatures could possibly increase K levels (Mira de Orduña, 2010). Potassium is involved in a variety of physiological processes, including enzyme activation in photosynthesis and respiration and the maintenance of cellular osmotic potential in plants (Salisbury and Ross, 1992). Potassium is mobile within the grapevine, and due to the relatively high requirements in vineyards, it is often applied as a fertilizer (Mosse et al., 2013). High K additions may negatively impact overall grapevine health and wine quality (Mpelasoka et al., 2003). Mainly because $\mathrm{K}$ is predominantly implicated in the neutralization of tartaric and malic acids in the berries, thereby affecting the acid characteristics of the grapes (Esteban et al., 1999), thus increasing the expected negative effect 
of the lack of wine acidity caused by climatic change (Leibar et al., 2016). Application of $\mathrm{K}$ to grapevines has also been found to influence anthocyanin levels and colour intensity (Mosse et al., 2013).

The characteristics of a particular soil have a large influence on the availability of water and the concentration of nutrients stored within it and, in turn, on the availability of nutrients for the grapevine. Grapevine development and yield are affected by soil water and nutrient storage and availability, and these latter, in turn, are influenced by soil depth and fertility, soil physical texture and structure, and soil chemistry, biology and organic matter content (van Leeuwen et al., 2004). Among all of the factors affecting soil nutrition, storage capacity and accessibility, soil texture, root depth and organic matter concentration deserve particular attention (Gonzalez-Dugo et al., 2010). In this regard, soil texture is an important component because it determines the amount of water that a soil can hold when fully wet and the amount of water and nutrients potentially available for grapevine uptake. In fact, any deficiency or excess of water can play a determinant role in root function and tissue mineral concentrations, causing unbalanced grapevine growth and poor yield (Ghaffari and Ferchichi, 2011).

Taking into account the importance of mineral nutrition and nutrient balance on grapevine, and within a climate change context, it is of crucial importance to know how changes in environmental factors, such as atmospheric $\mathrm{CO}_{2}$, temperature, relative humidity $(\mathrm{RH})$, and water availability, can affect plant nutritional status and the $\mathrm{K}$ concentration of must, which is central to wine quality. Nevertheless, there are few studies that have evaluated the combined effect of elevated $\mathrm{CO}_{2}$ concentrations, water availability and elevated temperature on grapevine nutrition. Because such studies are complex, difficult and expensive to execute under field conditions (Salazar-Parra et al., 2015). Even less frequent are studies where the impact of climate change on different soil types is evaluated. Therefore, the aim of this work was to evaluate the effect of the simulated year 2100 expected climate conditions: (1) a combination of elevated $\mathrm{CO}_{2}$, elevated temperature and reduced RH and (2) low water availability in comparison with current conditions on the nutritional status Vitis vinifera L. of cv. Tempranillo grown in soils of different textures.

\section{Materials and Methods}

\subsection{Potted plant establishment}

Dormant cuttings of Vitis vinifera L. of cv. Tempranillo clone RJ-43 were obtained in 2012 from an experimental vineyard at the Institute of Vine and Wine Sciences (Logroño, La Rioja, Spain). The cuttings were selected to obtain fruit-bearing cuttings, grapevine plants with one single cluster, in accordance with Leibar et al. (2015). Rooting was induced using indole butyric acid (September 2012) in a rock-wool heat-bed $\left(27^{\circ} \mathrm{C}\right.$ ) kept in a cool room $\left(4^{\circ} \mathrm{C}\right)$. One month later (October 2012), rooted cuttings were planted in $2 \mathrm{~L}$ plastic pots containing a mixture of perlite, vermiculite and peat (1:1:1, $\mathrm{v} / \mathrm{v} / \mathrm{v}$ ) and were transferred to the first greenhouse. Only a single flowering stem was allowed to develop on each plant, the rest were removed. Growth conditions until fruit set were $24 / 14{ }^{\circ} \mathrm{C}$ and $60 / 70 \% \mathrm{RH}$ (day/ night) with natural daylight. A supplemental system of high-pressure sodium lamps (HQI-TS 400W/D Osram, Augsburg, Germany) was triggered when photosynthetic photon flux density (PPFD) dropped below $1000 \mu \mathrm{mol}$ $\mathrm{m}^{-2} \mathrm{~s}^{-1}$ (14 h photoperiod). Humidity and temperature were controlled using M22W2HT4X transmitters (Rotronic Instrument Corp., Hauppauge, USA). The PPFD was monitored with a LI-190SZ quantum sensor (LICOR, Lincoln, USA). Plants were irrigated with a nutrient solution proposed by Ollat et al. (1998). The composition of the nutrient solution was $\mathrm{KNO}_{3}(2.5 \mathrm{mM})$, 
$\mathrm{MgSO}_{4} \cdot 7 \mathrm{H}_{2} \mathrm{O}(1.0 \mathrm{mM}), \mathrm{KH}_{2} \mathrm{PO}_{4}(1.0 \mathrm{mM}), \mathrm{Ca}\left(\mathrm{NO}_{3}\right)_{2}$ - $4 \mathrm{H}_{2} \mathrm{O}(2,5 \mathrm{mM}), \mathrm{MnCl}_{2} \bullet 4 \mathrm{H}_{2} \mathrm{O}(9.2 \mu \mathrm{M}), \mathrm{H}_{3} \mathrm{BO}_{3}(46.4$ $\mu \mathrm{M}), \mathrm{Na}_{2} \mathrm{MoO}_{4}(0.013 \mu \mathrm{M}), \mathrm{ZnSO}_{4} \cdot 7 \mathrm{H}_{2} \mathrm{O}(2.40 \mu \mathrm{M})$, $\mathrm{CuSO}_{4}(0.5 \mu \mathrm{M}), \mathrm{Na} \mathrm{Fe}(\mathrm{III})-\mathrm{EDTA}(45 \mu \mathrm{M})$.

\subsection{Experimental design}

At fruit set, the plants were transferred to growth chamber-greenhouses (GCGs) and divided into 12 homogeneous groups of 8-11 plants that would result in the treatments described in the next paragraph. These plants were selected to have similar intergroup variability in terms of grape bunch size, avoiding changes in berry quality due to sink strength. The transplant process was made with extreme care, and no significant amount of roots was lost.

Plants were subjected from fruit set to maturity (defined at 21-23 Brix) to the following conditions: i) two glasshouse conditions (GC), combining two $\mathrm{CO}_{2}$ concentrations, two temperatures (T) and two RH regimes. Simulated year 2100 expected climate conditions (FCC; $700 \mu \mathrm{mol} \mathrm{CO}_{2} / \mathrm{mol}$ air (ppm) $\mathrm{CO}_{2}, 28 / 18$ ${ }^{\circ} \mathrm{C}$, day/night and $33 / 53 \% \mathrm{RH}$, day/night) vs. current climate conditions (Curr; 390 ppm $\mathrm{CO}_{2}, 24 / 14{ }^{\circ} \mathrm{C}$ and 45/65\% RH). ii) Three soil textures: 41 (high), 19 (medium) and 8\% (low) of soil clay contents. And iii) two water availabilities: well-watered (WW) vs. expected future water deficit (WD: $60 \%$ of the water applied to the WW plants). As in potted plant establishment, the above-mentioned supplemental light system of high-pressure sodium lamps was used, and the photoperiod was $15 \mathrm{~h}$. Thus, 12 treatments were applied in a factorial design (2 glasshouse conditions x 3 soil textures x 2 water availabilities) as previously reported (Leibar et al. 2015). To prevent an edge effect, plants were rotated once a week within the corresponding greenhouse. Vegetative growth was not pruning-controlled. The $\mathrm{CO}_{2}, \mathrm{~T}$ and $\mathrm{RH}$ conditions projected by the IPCC (2007) for the period from
2070-2100 were simulated in two different GCGs, with increases in the $\mathrm{CO}_{2}$ concentration and temperature of up to $700 \mathrm{ppm}$ and $4{ }^{\circ} \mathrm{C}$, respectively. For the RH, ENSEMBLES models (based on IPCC data), based on the Max Planck Institute model (MPIECHAM5; Roeckner et al., 2003), state that the RH for the summer period will be $12 \%$ lower (change signal) at the end of the present century in the study area (i.e., in the grid or region of interest, "Denominación de Origen Calificada Rioja, DOCa Rioja").

Soils with a high red clay content are typical in DOCa Rioja (Barrios, 1994). To study the influence of three contrasting soil textures on grape yield and quality, a typical clay soil from La Rioja with high $\mathrm{pH}$ and low organic matter content was collected. It was mixed with sand to obtain three different soil textures: $41 \%$ clay (soil), 19\% clay (soil and sand 1:1, v/v) and 8\% clay (soil and sand 1:3, v/v) and put into $6 \mathrm{~L}$ plastic pots. Analysis by X-ray diffraction was carried out on the same soil type in the area where the sample was taken and showed that approximately $69 \%$ of the clay was illite, $10 \%$ chlorite, $12 \%$ kaolinite and $9 \%$ of one interlayer of vermiculite / smectite. The container capacity of each soil was measured as described by Leibar et al. (2015). The properties of the different soil:sand mixtures are shown in Table 1 . The $\mathrm{K}$ soil content was slightly low according to the reference contents proposed by the regional extension service in the more clayey soil and was very low in the less clayey soils. The soil P content was low in the three soils, and the Mg soil content was low for sandy soils and high for the more clayey ones (Table 1).

Plants under WW conditions were maintained at container capacity ( $20-35 \%$ of soil water content), where soil water content was maintained above $20 \%$. This represented daily inputs of approximately 500-800 $\mathrm{mL}$ of water or nutrient solution. The same amount of water was applied to all plants in order to observe the water availability of each soil type. WD plants received 
$60 \%$ of the water applied to those of WW. This water deficit level was chosen based on the model from the Max Planck Institute, which establishes that, in the summer period, precipitations will be $40 \%$ lower in DOCa Rioja at the end of the present century. Soil water sensors (EC-5 volumetric water content sensor, Decagon Devices, Washington) were placed into the pots to control irrigation. Irrigation was done from fruit set to ripeness, with a half-strength Hoagland nutrient solution or distilled water in order to provide the same amount of nutrients to all treatments.

Table 1. Physico-chemical properties of the three texturally different soils from DOCa Rioja used in the experiment.

\begin{tabular}{|c|c|c|c|}
\hline Physico-chemical soil properties & High clay & Medium clay & Low clay \\
\hline Sand $(\%)^{\mathrm{a}}$ & 8 & 58 & 86 \\
\hline Silt $(\%)^{\mathrm{a}}$ & 51 & 23 & 6 \\
\hline Clay $(\%)^{\mathrm{a}}$ & 41 & 19 & 8 \\
\hline Texture ${ }^{a}$ & Silty clay & Sandy loam & Loamy sand \\
\hline Bulk density $\left(\mathrm{g} \mathrm{cm}^{-3}\right)$ & 1.230 & 1.325 & 1.410 \\
\hline $\mathrm{pH}^{\mathrm{b}}$ & 8.84 & 9.21 & 9.39 \\
\hline Organic matter $(\%)^{\mathrm{a}}$ & $<0.01$ & $<0.01$ & $<0.01$ \\
\hline Carbonates $(\%)^{\mathrm{a}}$ & 70.18 & 19.39 & 6.32 \\
\hline Active lime $(\%)$ & 10.17 & 4.61 & 0.00 \\
\hline$N(\%)^{\mathrm{c}}$ & 0.03 & 0.01 & 0.01 \\
\hline $\mathrm{P}\left(\mathrm{mg} \mathrm{kg}^{-1}\right)^{\mathrm{a}}$ & 1.83 & 1.39 & 1.27 \\
\hline $\mathrm{Mg}\left(\text { meq } 100 \mathrm{~g}^{-1}\right)^{\mathrm{a}}$ & 5.26 & 2.72 & 1.15 \\
\hline $\mathrm{K}\left(\mathrm{mg} \mathrm{kg}^{-1}\right)^{\mathrm{a}}$ & 138 & 67 & 29 \\
\hline $\mathrm{Na}\left(\text { meq } 100 \mathrm{~g}^{-1}\right)^{\mathrm{a}}$ & 0.11 & bld & bld \\
\hline $\mathrm{Ca}\left(\text { meq } 100 \mathrm{~g}^{-1}\right)^{\mathrm{a}}$ & 20.51 & 18.55 & 15.50 \\
\hline $\operatorname{CEC}\left(\text { meq } 100 \mathrm{~g}^{-1}\right)^{\mathrm{a}}$ & 12.75 & 6.21 & 2.43 \\
\hline
\end{tabular}

aTexture by pipette method, organic matter, carbonates, $\mathrm{P}, \mathrm{Mg}, \mathrm{K}$, $\mathrm{Na}, \mathrm{Ca}, \mathrm{CEC}$ (MAPA, 1994); ${ }^{\mathrm{b}} \mathrm{pH}$ (1:2.5 soil:water); ${ }^{\mathrm{c} T o t a l} \mathrm{~N}$ (dry combustion using an LECO TruSpec $® 13 \mathrm{CHNs}$ ); bld = below limit of detection

\subsection{Measurements}

Leaf blade samples opposite from the cluster were collected in all of the plants, as stated by Benito et al. (2013), at veraison and maturity. Samples were dried at $70{ }^{\circ} \mathrm{C}$ in a forced-air oven for $48 \mathrm{~h}$. Blades from every two plants within the same treatment were pooled in order to have 4-6 biological replicates per treatment; therefore, two plants made one biological replicate. Samples of $0.5 \mathrm{~g}$ were taken and the $\mathrm{K}, \mathrm{Mg}, \mathrm{Na}, \mathrm{Ca}, \mathrm{Mn}, \mathrm{Fe}$ and $\mathrm{Zn}$ concentrations were determined by flame atomic absorption spectrometry (SpectrAA-200, Varian, Australia) following digestion with a mixture of $\mathrm{HNO}_{3} /$ $\mathrm{HClO}_{4}$. Nitrogen was measured using dry combustion in an elemental analyser (TruSpec CN, Leco, St. Joseph, Michigan) from a $0.1 \mathrm{~g}$ sample.

All of the plants were harvested individually at maturity, that is, when the berries reached 21-23 Brix. The leaves were counted, and the total (leaves, shoots and roots) dry weight was calculated after drying in an oven.

To analyse the $\mathrm{K}$ concentration of must, 50 berries per plant were randomly collected. Berries from two different plants within the same treatment (8-11 plants) were pooled in order to have 4-6 biological replicates (two plants made one biological replicate), making 100 berries per sample. Berries were weighed and ground in a blender (Omni Mixer). Part of the extract $(10 \mathrm{ml})$ was centrifuged at $4.302 \mathrm{~g}$ for $10 \mathrm{~min}$ and diluted 10 times. Then, it was used to determine the $\mathrm{K}$ concentration by flame atomic absorption spectrometry (AAS, Varian) following a similar digestion procedure as the leaf samples.

\subsection{Statistical analysis}

Statistical analysis was carried out with R software (R Development Core Team, Vienna, Austria). 
The data were analysed with a 3-way analysis of variance to investigate the effects of glasshouse condition, soil texture, water availability and their interactions. The results were considered statistically significant at $p<0.05$. The Tukey HSD test was used as a post hoc technique when the effects of treatments were statistically significant. When there was any interaction between factors, further analysis of variance was required, separating factors into levels. Data are presented as the means \pm standard error (SE).

\section{Results}

The FCC leaf blades tended to have lower nutrient concentration than those of Curr, although significant differences were only observed for $\mathrm{N}$ and $\mathrm{Ca}$ at veraison veraison (Table 2) and $\mathrm{N}$ and $\mathrm{Zn}$ at full maturity (Table $3)$. WD leaf blades had generally higher concentrations of most of the nutrients compared to those of WW, even though significant differences were only found for $\mathrm{Na}$ at veraison (Table 2) and $\mathrm{Mn}$ at full maturity (Table 3). However, the K concentration was $14.29 \%$ higher in leaf blades at full maturity in the WW than WD treatments (Tables 3). Soil texture did not affect plant nutrition at veraison (Table 2). Nevertheless, at full maturity, plants grown under more clayey soils had a higher $\mathrm{Ca}$ and $\mathrm{Mn}$ concentration in their blades than those grown under the other two soil textures (Table $3)$. There was no significant interaction among factors, with the exception of Mn and Fe blade concentration at veraison (Table 2), where glasshouse conditions (GC) and water availability interacted.

Table 2. Average concentrations and standard errors of macronutrients and micronutrients in grapevine cv. Tempranillo leaf blades at veraison, grown under two glasshouse conditions (GC): current conditions (Curr) and future expected conditions (FCC); two water availabilities (WA): well-watered (WW) and future expected water deficit (WD); and three soil textures (ST): 41 (high), 19 (medium) and 8\% (low) clay contents. Significance codes: $\mathrm{ns}=$ no significance differences, $* * * p<0.001, * * 0.001 \leq p<0.01, * 0.01 \leq p<0.05$. Capital letters A and B indicate significant differences $(p<0.05)$ between FCC and Curr. Small letters a and $\mathrm{b}$ indicate significant differences $(p<0.05)$ between WW and WD. INT $=$ interaction between GC and WA.

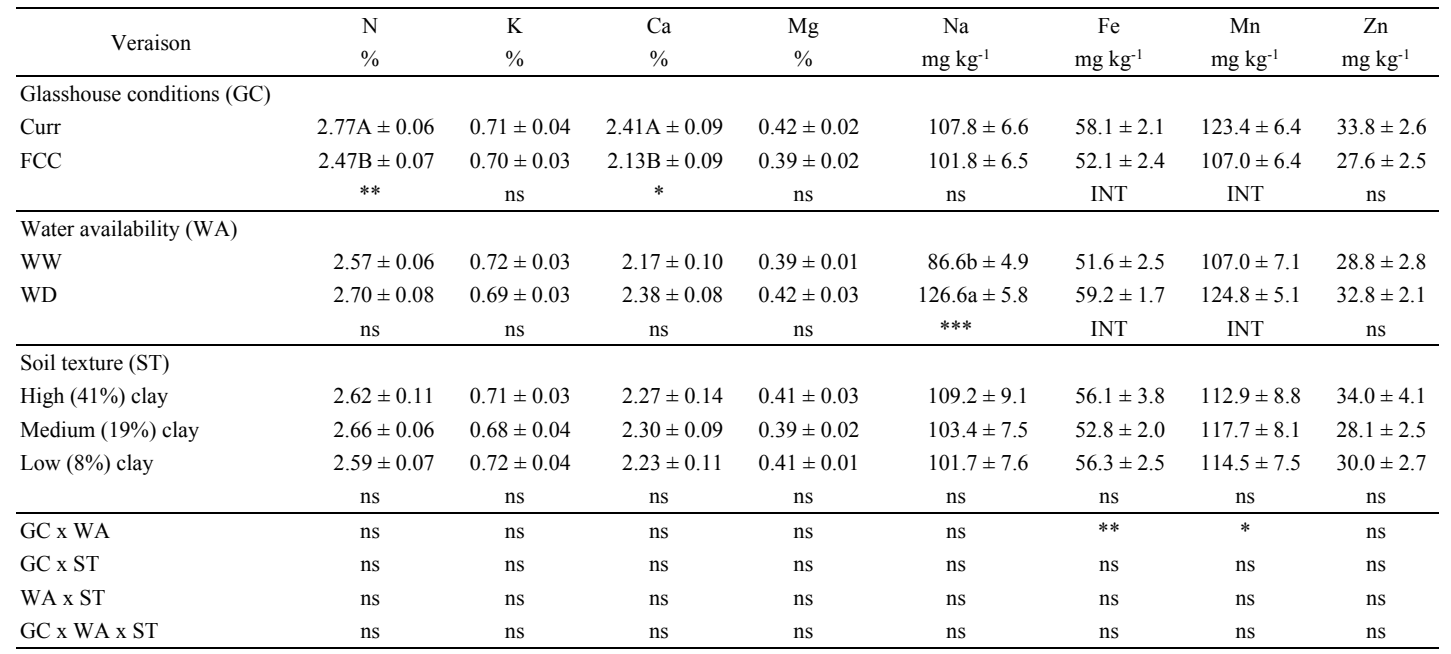


FCC significantly reduced the concentration of $\mathrm{Mn}$ and Fe, but only for WW (Figure 1). Nutrient leaf concentrations were similar when comparing veraison and full maturity values. Sodium was the only element decreasing slightly its concentration at the end of the cycle.

Table 3. Average concentrations and standard errors of macronutrients and micronutrients in grapevine cv. Tempranillo leaf blades at full maturity, grown under two glasshouse conditions (GC): current conditions (Curr) and future expected conditions (FCC); two water availabilities (WA): well-watered (WW) and future expected water deficit (WD); and three soil textures (ST): 41 (high), 19 (medium) and $8 \%$ (low) clay contents. Significance codes: ns $=$ no significance differences, $* * * p<0.001, * * 0.001 \leq p<0.01, * 0.01 \leq p<0.05$. Capital letters A and B indicate significant differences $(p<0.05)$ between FCC and Curr. Small letters a and $\mathrm{b}$ indicate significant differences $(p<0.05)$ between WW and WD. Capital letters $\mathrm{Y}$ and $\mathrm{Z}$ within the same parameter indicate significant differences $(p<0.05)$ among different soil textures.

\begin{tabular}{|c|c|c|c|c|c|c|c|c|}
\hline Full maturity & $\begin{array}{l}\mathrm{N} \\
\%\end{array}$ & $\begin{array}{l}\mathrm{K} \\
\%\end{array}$ & $\begin{array}{l}\mathrm{Ca} \\
\%\end{array}$ & $\begin{array}{c}\mathrm{Mg} \\
\%\end{array}$ & $\begin{array}{c}\mathrm{Na} \\
\mathrm{mg} \mathrm{kg}^{-1}\end{array}$ & $\begin{array}{c}\mathrm{Fe} \\
\mathrm{mg} \mathrm{kg}^{-1}\end{array}$ & $\begin{array}{c}\mathrm{Mn} \\
\mathrm{mg} \mathrm{kg}^{-1}\end{array}$ & $\begin{array}{c}\mathrm{Zn} \\
\mathrm{mg} \mathrm{kg}^{-1}\end{array}$ \\
\hline \multicolumn{9}{|c|}{ Glasshouse conditions (GC) } \\
\hline Curr & $2.60 \mathrm{~A} \pm 0.07$ & $0.73 \pm 0.04$ & $2.44 \pm 0.09$ & $0.38 \pm 0.03$ & $83.4 \pm 4.2$ & $62.6 \pm 3.0$ & $110.3 \pm 6.2$ & $47.3 \mathrm{~A} \pm 3.6$ \\
\hline \multirow[t]{2}{*}{$\mathrm{FCC}$} & $2.25 \mathrm{~B} \pm 0.05$ & $0.65 \pm 0.03$ & $2.55 \pm 0.10$ & $0.43 \pm 0.03$ & $83.5 \pm 5.4$ & $55.51 \pm 2.2$ & $103.7 \pm 5.7$ & $28.6 \mathrm{~B} \pm 1.7$ \\
\hline & $* * *$ & $\mathrm{~ns}$ & $\mathrm{~ns}$ & ns & ns & $\mathrm{ns}$ & $\mathrm{ns}$ & $* * *$ \\
\hline \multicolumn{9}{|l|}{ Water availability (WA) } \\
\hline WW & $2.40 \pm 0.07$ & $0.74 \mathrm{a} \pm 0.03$ & $2.42 \pm 0.10$ & $0.41 \pm 0.03$ & $77.2 \pm 4.3$ & $57.3 \pm 2.7$ & $93.2 \mathrm{~b} \pm 5.9$ & $37.3 \pm 3.3$ \\
\hline \multirow[t]{2}{*}{ WD } & $2.44 \pm 0.07$ & $0.63 b \pm 0.04$ & $2.58 \pm 0.09$ & $0.41 \pm 0.03$ & $90.3 \pm 5.2$ & $60.6 \pm 2.6$ & $121.5 \mathrm{a} \pm 4.8$ & $37.9 \pm 3.1$ \\
\hline & ns & $*$ & ns & ns & $\mathrm{ns}$ & $\mathrm{ns}$ & $* * *$ & $\mathrm{~ns}$ \\
\hline \multicolumn{9}{|l|}{ Soil texture (ST) } \\
\hline High $(41 \%)$ clay & $2.44 \pm 0.11$ & $0.69 \pm 0.03$ & $2.69 \mathrm{Y} \pm 0.14$ & $0.43 \pm 0.05$ & $83.9 \pm 4.6$ & $64.1 \pm 3.2$ & $117.0 \mathrm{Y} \pm 7.7$ & $40.1 \pm 3.5$ \\
\hline Medium (19\%) clay & $2.52 \pm 0.08$ & $0.71 \pm 0.04$ & $2.45 \mathrm{YZ} \pm 0.10$ & $0.41 \pm 0.03$ & $89.0 \pm 5.2$ & $56.8 \pm 2.1$ & $111.4 \mathrm{YZ} \pm 7.5$ & $40.5 \pm 4.3$ \\
\hline \multirow[t]{2}{*}{ Low ( $8 \%$ ) clay } & $2.30 \pm 0.07$ & $0.68 \pm 0.05$ & $2.35 \mathrm{Z} \pm 0.09$ & $0.38 \pm 0.03$ & $77.5 \pm 7.3$ & $56.1 \pm 3.9$ & $92.7 \mathrm{Z} \pm 5.8$ & $32.4 \pm 3.9$ \\
\hline & ns & $\mathrm{ns}$ & $*$ & ns & $\mathrm{ns}$ & $\mathrm{ns}$ & * & $\mathrm{ns}$ \\
\hline GC x WA & ns & ns & ns & ns & ns & ns & ns & ns \\
\hline GC $\times$ ST & $\mathrm{ns}$ & $\mathrm{ns}$ & $\mathrm{ns}$ & ns & $\mathrm{ns}$ & $\mathrm{ns}$ & $\mathrm{ns}$ & $\mathrm{ns}$ \\
\hline WA $\times$ ST & ns & $\mathrm{ns}$ & $\mathrm{ns}$ & ns & $\mathrm{ns}$ & $\mathrm{ns}$ & ns & ns \\
\hline GC $x$ WA $x$ ST & ns & ns & ns & ns & ns & $\mathrm{ns}$ & ns & ns \\
\hline
\end{tabular}
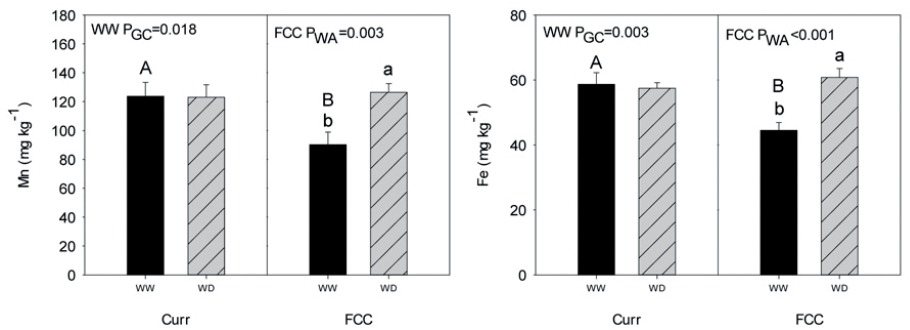

Figure 1. Glasshouse conditions (GC) and water availability (WA) factor interactions for leaf Mn and Fe concentrations at veraison in grapevine cv. Tempranillo. Different capital letters indicate significant differences $(p<0.05)$ between the future expected conditions (FCC) and current conditions (Curr) treatments within each water availability treatment (WW ${ }_{\text {PGC }}$ ). Different small letters indicate significant differences $(p<0.05)$ between the well-watered (WW) and future expected water deficit WD within each glasshouse condition $\left(\mathrm{FCC}_{\mathrm{PWA}}\right)$. 
Regarding the $\mathrm{K}$ concentration of must, there was no significant difference between FCC and Curr (Table 4). The $\mathrm{K}$ concentration was $6.19 \%$ higher for must from the WW than the WD treatments (Table 4). Berries from plants grown under the more clayey soils had $7.56 \%$ and $3.89 \%$ higher $\mathrm{K}$ concentration in the must than berries from plants grown under the other soil textures (Table 4).

Table 4. Mean and standard error values of the K concentration in the must of cv. Tempranillo grapevines grown under two glasshouse conditions (GC): current conditions (Curr) and future expected conditions (FCC); two water availabilities (WA): well-watered (WW) and future expected water deficit (WD); and three soil textures (ST): 41 (high), 19 (medium) and $8 \%$ (low) clay contents. Significance codes: $\mathrm{ns}=$ no significant differences, ${ }^{* * *} p<0.001, * * 0.001 \leq p<0.01$, $* 0.01 \leq p<0.05$. Different letters indicate significant differences $(p<0.05)$ among levels of the applied factor.

\begin{tabular}{lr}
\hline & \multicolumn{1}{l}{$\mathrm{K}\left(\mathrm{g} \mathrm{kg}^{-1}\right)$} \\
\hline GC & $2.37 \pm 0.04$ \\
Curr & $2.29 \pm 0.03$ \\
FCC & \\
& \\
\hline WA & $2.40 \pm 0.04 \mathrm{a}$ \\
WW & $2.26 \pm 0.03 \mathrm{~b}$ \\
WD & \\
& \\
\hline ST & \\
High (41\%) clay & $\mathrm{ns}$ \\
Medium (19\%) clay & $2.33 \pm 0.05 \mathrm{ab}$ \\
Low (8\%) clay & $2.25 \pm 0.03 \mathrm{~b}$ \\
GC x ST & \\
\hline GC x WA & \\
\hline
\end{tabular}

Furthermore, no significant differences in the leaf dry weight or in the dry weight of other organs (shoots and roots) were observed in plants grown under different GC and soil textures (Table 5). However, wellwatered plants had $69.55 \%$ higher leaf dry weights and $20.67 \%$ higher total dry weights than plants subjected to water stress (Table 5).

Table 5. Averages of total leaf dry weight and total weight and standard errors of cv. Tempranillo grapevines at full maturity, grown under two glasshouse conditions (GC): current conditions (Curr) and future expected conditions (FCC); two water availabilities (WA): well-watered (WW) and future expected water deficit (WD); and three soil textures (ST): 41 (high), 19 (medium) and 8\% (low) clay contents. Significance codes: $\mathrm{ns}=$ no significance differences, ${ }^{* * *} p<$ $0.001, * * 0.001 \leq p<0.01, * 0.01 \leq p<0.05$. Different small letters indicate significant differences $(\mathrm{p}<0.05)$ between WW and WD.

\begin{tabular}{lcc}
\hline & $\begin{array}{c}\text { Total leaf } \\
\text { dry weight }(\mathrm{g})\end{array}$ & $\begin{array}{c}\text { Total weight } \\
(\mathrm{g})\end{array}$ \\
\hline GC & & \\
Curr & $17.70 \pm 1.01$ & $116.02 \pm 3.10$ \\
FCC & $16.13 \pm 0.87$ & $113.20 \pm 3.22$ \\
& $\mathrm{~ns}$ & $\mathrm{~ns}$ \\
\hline WA & $21.16 \mathrm{a} \pm 0.93$ & $124.99 \mathrm{a} \pm 3.27$ \\
WW & $12.48 \mathrm{~b} \pm 0.49$ & $103.59 \mathrm{~b} \pm 2.23$ \\
WD & $* * *$ & $* * *$ \\
\hline ST & $16.66 \pm 1.35$ & $114.62 \pm 3.91$ \\
High (41\%) clay & $16.92 \pm 1.11$ & $114.50 \pm 3.51$ \\
Medium (19\%) clay & $17.20 \pm 1.06$ & $114.60 \pm 4.22$ \\
Low (8\%) clay & $\mathrm{ns}$ & $\mathrm{ns}$ \\
\hline GC x WA & $\mathrm{ns}$ & $\mathrm{ns}$ \\
GC x ST & $\mathrm{ns}$ & $\mathrm{ns}$ \\
WA x ST & $\mathrm{ns}$ & $\mathrm{ns}$ \\
GC x WA x ST & $\mathrm{ns}$ & $\mathrm{ns}$ \\
\hline
\end{tabular}




\section{Discussion}

Potassium, $\mathrm{Mg}$ and $\mathrm{Mn}$ concentrations of leaf blades sampled at veraison were within the normal range for cv. Tempranillo for DOCa Rioja (K 0.65-0.97\%, Mg $0.36-0.51 \%$ and $\mathrm{Mn} 69-119 \mathrm{mg} \mathrm{kg}^{-1}$ ) (García-Escudero et al., 2013). Lower values were observed for $\mathrm{Ca}$ and $\mathrm{Fe}\left(\mathrm{Ca}<2.6 \%\right.$ and $\left.\mathrm{Fe}<112 \mathrm{mg} \mathrm{kg}^{-1}\right)$ and higher values were found for $\mathrm{Zn}$ and $\mathrm{N}\left(\mathrm{Zn}>24 \mathrm{mg} \mathrm{kg}^{-1}\right.$ and $\mathrm{N}>$ $2.5 \%)$. Nutrient values at maturity were also very similar to those found by García-Escudero et al. (2013).

The lower nutrient concentration in leaf blades under FCC plants (in particular, $\mathrm{N}$ and $\mathrm{Ca}$ at veraison and $\mathrm{N}$ and $\mathrm{Zn}$ at full maturity) was associated with a greater number of leaves on these plants $(29.53 \pm$ 1.62) in comparison to those plants grown under Curr (22.49 \pm 1.30$)$ (Leibar et al., 2015). Greater leaf biomasses usually resulted in a dilution of nutrients and, therefore, lower nutrient concentrations (Ata-UlKarim et al., 2014). In our case, this effect could be discarded since there were no differences in biomass in the FCC plants. Martins et al. (2014) found that leaf mineral nutrient concentrations are frequently observed to decline in the biomass in response to exposure to enhanced atmospheric $\mathrm{CO}_{2}$ concentrations. This has been largely attributed to higher growth rates but also to increased amounts of non-structural carbohydrates (mainly starch) or to lower leaf transpiration rates (Thiec et al., 1995). As reported by Leibar et al. (2015), at veraison there were no differences in stomatal conductance, but at maturity, waterstressed plants grown under FCC $(0.63 \pm 0.10 \mathrm{mmol}$ $\left.\mathrm{H}_{2} \mathrm{O} \mathrm{m}^{-2} \mathrm{~s}^{-1}\right)$ had lower leaf transpiration compared to plants grown under Curr $\left(1.22 \pm 0.17 \mathrm{mmol} \mathrm{H}_{2} \mathrm{O} \mathrm{m}^{-2}\right.$ $\mathrm{s}^{-1}$ ). Among well-watered plants, there were no differences between FCC and Curr in leaf transpiration (Leibar et al., 2015). Therefore, the lower $\mathrm{Ca}$ and $\mathrm{Zn}$ concentrations under FCC might be explained by a higher transpiration rate only when plants were grown under a water deficit. The reduced leaf $\mathrm{N}$ concentration of FCC plants, at veraison and full maturity, is in line with Salazar-Parra et al. (2015) and Leibar et al. (2015), who reported lower $\mathrm{N}$ concentrations in plants grown under elevated $\mathrm{CO}_{2}$ as evidence of photosynthetic acclimation (down-regulation of assimilation) to elevated $\mathrm{CO}_{2}$.

The higher nutrient concentrations of leaf blades in the water-stressed plants (significant differences only for $\mathrm{Na}$ at veraison and $\mathrm{Mn}$ at full maturity) could be because the well-watered plants had higher leaf dry weight and higher total dry weight than the plants subjected to water stress. This caused a dilution effect and, consequently, nutrients were more concentrated in plants grown under WD (Ata-Ul-Karim et al., 2014). On the other hand, Wang et al. (2008) suggested that the capacity to maintain $\mathrm{Na}$ in plant tissues under drought is part of the water stress avoidance mechanism. In contrast, the $\mathrm{K}$ concentration was higher in leaf blades and must at full maturity in the WW than WD treatment. Similarly, Dundon and Smart (1984) stated that K availability and uptake is reduced under conditions of limited soil water. In this regard, Esteban et al. (1999) reported that the absorption of $\mathrm{K}$ may be limited in dry soils. Klein et al. (2000) reported an increase of $\mathrm{K}$ in leaf blades under irrigation, which indicates a general increase in grapevine $\mathrm{K}$ status. Therefore, an increase in the root uptake of $\mathrm{K}$ under irrigated conditions may account for elevated grapevine and berry $\mathrm{K}$ accumulation (Mpelasoka et al., 2003), which was observed in this experiment. Irrigation enhances the dissolution of $\mathrm{K}$ from clay particles and its movement in the soil solution, which facilitates its supply to roots and a higher plant uptake (Klein et al., 2000). In addition, Rühl et al. (1992) stated that a water deficit might reduce mineral absorption because of lower root activity and root growth, as Leibar et al. (2016) observed for root growth in this experiment. 
The finding of an absence of a soil texture effect at veraison is in agreement with Shange and Conradie (2012), who did not observe a consistent pattern of soil parent materials influence on leaf blade nutritional status. The higher leaf $\mathrm{Ca}$ and $\mathrm{Mn}$ concentrations at full maturity in grapevines grown in more clayey soil may be related to the higher initial nutrient content and cation exchange capacity (CEC) of these soils, as clay particles can hold nutrients due to their high CEC (Pal and Marschner, 2016). In our study, sandy soils had higher pH (9.39) than clayey soils (8.84); similarly, Pearson and Goheen (1988) and Rengel (2015) stated that Mn deficiency symptoms were more likely to occur in alkaline sandy soils, as Mn availability decreases in high $\mathrm{pH}$ soils. However, in our case, Mn values were within normal ranges, even high in all treatments, and no visual symptoms of Mn deficiency were observed. Although the $\mathrm{K}$ concentration in leaf blades did not exhibit significant differences among different soil textures, berries from plants grown under more clayey soils had higher $\mathrm{K}$ concentration in the must than berries from plants grown under other soil textures. This indicates that grape berries are a strong sink for K, particularly during ripening, as observed by Mpelasoka et al. (2003). Even if the three soils received the same high $\mathrm{K}$ input (206.94 g), and this amount was much higher than total $\mathrm{K}$ leaf biomass + must extraction $(0.12+0.56 \mathrm{~g})$, the higher exchangeable $\mathrm{K}$ content, higher $\mathrm{CEC}$ and the predominance of 2:1 clay minerals as illites may explain the higher $\mathrm{K}$ concentration in the must. The ability to fix or release $\mathrm{K}$ from 2:1 clay minerals led to authors such as Barré et al. (2008) to postulate that they behave as a $\mathrm{K}$ reservoir in soils. Esteban et al. (1999) asserted that the K concentration in must mainly comes from root absorption, which is determined by the level of assimilable $\mathrm{K}$ in the soil. The capability of our soil to provide $\mathrm{K}$ was so high that the $\mathrm{K}$ concentration of the must was higher in plants grown in the clayey soil, even when the root system was less developed (Leibar et al., 2016). A positive correlation has been found between the $\mathrm{K}$ concentration and $\mathrm{pH}$ of grape berry juice (Mpelasoka et al., 2003), high $\mathrm{pH}$ adversely affecting the stability of the wine. It is well known how climate change (higher $\mathrm{T}$ and higher $\mathrm{CO}_{2}$ concentration) will worsen must and wine acidity (Jones et al., 2005; Leibar et al., 2016); and soils with medium-high $\mathrm{K}$ content could contribute to this $\mathrm{pH}$ increase. Nevertheless, long-term field experiments under climate change conditions would be necessary to extract more definitive conclusions. The effects could be more or less pronounced when grapevines grow under these conditions for several years. As an example it is largely stated that plants acclimated its photosynthesis rate to high $\mathrm{CO}_{2}$ atmospheric concentration as it was reported at this experiment (Leibar et al., 2015).

\section{Conclusions}

The elevated $\mathrm{CO}_{2}$ and temperature and reduced $\mathrm{RH}$ expected in climate change predictions resulted in $\mathrm{N}$ concentration reductions in leaf blades regardless of their phenological stage. Future expected water deficits significantly altered grapevine nutritional status, thereby leading to higher concentrations of $\mathrm{Na}$ at veraison and $\mathrm{Mn}$ at maturity compared to well-watered plants. The higher aerial biomass was probably the cause of this dilution effect in the treatment with no water deficit. The exception was $\mathrm{K}$, which showed lower concentrations in the leaves and in the must under the water deficit treatment. Soil texture influenced concentrations of $\mathrm{Ca}$ and $\mathrm{Mn}$ in the leaves and $\mathrm{K}$ in the must, as they were higher for grapevines in more clayey soils. Even when $\mathrm{K}$ input from fertilization was much higher than plant $\mathrm{K}$ extraction, a greater availability of soil $\mathrm{K}$ could increase the $\mathrm{K}$ concentration in plant tissues and must. Thus, special care should be taken with soils that have a great ability to supply $\mathrm{K}$, because this property is difficult to change. This increased $\mathrm{K}$ concentration of 
must could be a problem in terms of wine acidity loss, especially since one of the adverse effects of climate change (elevated $\mathrm{CO}_{2}$ and $\mathrm{T}$ ) will also be lower must acidity. However, it is worth mentioning that future expected reduced water availability would cause a decrease in the $\mathrm{K}$ concentration of must.

Abbreviations: $\mathrm{T}=$ temperature; $\mathrm{RH}=$ relative humidity; $\mathrm{FCC}=$ simulated year 2100 expected $\mathrm{CO}_{2}, \mathrm{~T}$ and $\mathrm{RH}$ conditions; Curr $=$ current $\mathrm{CO}_{2}, \mathrm{~T}$ and $\mathrm{RH}$ conditions; WA = water availability; $\mathrm{WW}=$ well watered; WD = future expected water deficit; ST = soil texture; $\mathrm{CEC}$ - cation exchange capacity.

\section{Acknowledgements}

We thank the Department of Economic Development and Competitiveness of the Basque Government and Aragón Government (A03 research group) for financial support. Urtzi Leibar was the recipient of a grant from "Fundación Cándido Iturriaga y María Doñabeitia". The authors would like to thank A. Urdiain and M. Oyarzun (Universidad de Navarra) for their excellent technical assistance and the Institute of Vine and Wine Sciences (Logroño, La Rioja, Spain) for supplying the dormant cuttings.

\section{References}

Ata-Ul-Karim, S.T., Zhu, Y., Yao, X., Cao, W. 2014. Determination of critical nitrogen dilution curve based on leaf area index in rice. Field Crop Res. $167,76-85$.

Barré, P., Velde, B., Fontaine, C., Catel, N., Abbadie, L. 2008. Which 2:1 clay minerals are involved in the soil potassium reservoir? Insights from potassium addition or removal experiments on three temperate grassland soil clay assemblages. Geoderma. 146, 216-223.
Barrios, A. 1994. Mapa de Suelos de La Rioja Alavesa E: 1/50000. Departamento de Agricultura de la Diputación Foral de Álava. Servicio de Estudios y Relaciones Comunitarias. Vitoria-Gasteiz. España.

Benito, A., Romero, I., Domínguez, N., García-Escudero, E., Martín, I. 2013. Leaf blade and petiole analysis for nutrient diagnosis in Vitis vinifera L. cv. Garnacha tinta. Aust. J. Grape Wine Res. 19, 285-298.

Brataševec, K., Sivilotti, P., Vodopivec, B.M. 2013. Soil and foliar fertilization affects mineral contents in Vitis vinifera L. cv. 'rebula' leaves. J. Soil Sci. Plant Nutr. 13(3), 650-663.

Dundon, C.G., Smart, R.E. 1984. Effects of water relations on the potassium status of Shiraz vines. Am. J. Enol. Viticult. 35, 40-45.

Esteban, M.A., Villanueva, M.J., Lisarrague, J.R. 1999. Effect of irrigation on changes in berry composition of Tempranillo during maturation. Sugars, organic acids, and mineral elements. Am. J. Enol. Viticult. 50, 418-434.

García-Escudero, E., Romero, I., Benito, A., Domínguez, N. Martín, I. 2013. Reference levels for leaf nutrient diagnosis of cv Tempranillo Grapevine in the Rioja appellation. Commun. Soil Sci. Plan. 44, 645-654.

Ghaffari, S., Ferchichi, A. 2011. Characterization of Tunisian grapevine (Vitis vinifera L.) cultivars using leaves morphological traits and mineral composition. Rom. Biotechnol. Lett. 5(16), 6556-6563.

Gonzalez-Dugo, V., Durand, J.L., Gastal, F. 2010. Water deficit and nitrogen nutrition of crops. A review. Agron. Sustain. Dev. 30, 529-544.

IPCC. 2007. Climate change and its impacts in the near and long term under different scenarios. In: Pachauri RK, Reisinger A (eds) Climate change 2007: synthesis report. Contribution of Working Groups I, II and III to the Fourth Assessment Report of the Intergovernmental Panel on Climate Change Core Writing Team. IPCC, Geneva. 
IPCC. 2013. Climate Change 2013: The Physical science basis. Contribution of working group I to the fifth assessment report of the intergovernmental panel on climate change, Cambridge University Press, Cambridge, United Kingdom and New York, NY, USA.

Jones, G.V., White, M.A., Cooper, O.R., Storchmann, K. 2005. Climate change and global wine quality. Climatic Change 73, 319-343.

Klein, I., Strime, M., Fanberstein, L., Mani, Y. 2000. Irrigation and fertigation effects on phosphorus and potassium nutrition of wine grapes. Vitis. 39, 55-62.

Leibar, U., Aizpurua, A., Unamunzaga, O., Pascual, I., Morales, F. 2015. How will climate change influence grapevine $\mathrm{cv}$. Tempranillo photosynthesis under different soil textures?. Photosyn. Res. 124, 199-215.

Leibar, U., Pascual, I., Morales, F., Aizpurua, A., Unamunzaga, O. 2016. Grape yield and quality responses to simulated year 2100 expected climatic conditions under different soil textures. J. Sci. Food Agr. Accepted. DOI: 10.1002/jsfa.8086.

MAPA. 1994. Métodos de Análisis para Suelos. En: Métodos Oficiales de Análisis. Tomo III. Ministerio de Agricultura, Pesca y Alimentación (MAPA), Madrid.

Martins, L.D., Tomaz, M.A., Lidon, F.C., DaMatta, F.M., Ramalho, J.C. 2014. Combined effects of elevated [CO2] and high temperature on leaf mineral balance in Coffea spp. Plants. Climatic Change 126, 365-379.

Mira de Orduña, R. 2010. Climate change associated effects on grape and wine quality and production. Food Res. Int. 43, 1844-1855.

Mosse, K.P.M., Lee, J., Leachman, B.T., Parikh, S.J., Cavagnaro, T.R., Patti, A.F., Steenwerth, K.L. 2013. Irrigation of an established vineyard with winery cleaning agent solution (simulated winery wastewater): Vine growth, berry quality, and soil chemistry. Agric. Water Manage. 123, 93-102.
Mpelasoka, B.S., Schachtman, D.P., Treeby, M.T., Thomas, M.R. 2003. A review of potassium nutrition in grapevine with special emphasis on berry accumulation. Aust. J. Grape Wine Res. 9, 154-168.

Ollat, N., Geny, L., Soyer, J. 1998. Les boutures fructifères de vigne: validation d'un modèle d'etude du development de la physiologie de la vigne, I Caractèristiques de l'appareil vegetative. J. Int. Sci. Vigne Vin 32, 1-9.

Pearson, R.C., Goheen, A.C. 1988. Compendium of Grape Diseases 4th Edition. The American Phytopathological Society, USA.

Proffitt, T., Campbell-Clause, J. 2012. Managing grapevine nutrition and vineyard soil health. http://www.perthregionnrm.com/media/57989/ grapevine_nutrition_amended.pdf(accessed 2016/09/25).

Rengel, Z. 2015. Availability of Mn, Zn and Fe in the rhizosphere. J. Soil Sci. Plant Nutr. 15(2): 397-409.

Roeckner, E., Bäuml, G., Bonaventura, L., Brokopf, R., Esch, M., Giorgetta, M., Hagemann, S., Kirchner, I., Kornblueh, L., Manzini, E., Rhodin, A., Schlese, U., Schulzweida, U., Tompkins, A. 2003. The atmosphere general circulation model ECHAM5, part 1: model description. Technical report no. 349: 127 pp, Max-Planck-Institut für Meteorologie.

Romero, I., García-Escudero, E., Martín, I. 2010. Effects of leaf position on blade and petiole mineral nutrient concentration of Tempranillo grapevine (Vitis vinifera L.). Am. J. Enol. Viticult. 61: 544-550.

Rühl, E.H., Fuda, A.P., Treeby, M.T. 1992. Effect of potassium, magnesium and nitrogen supply on grape berry composition of Riesling, Chardonnay and Cabernet Sauvignon vines. Aust. J. Exp. Agr. 32, 645-649. 
Pal, S., Marschner, P. 2016. Influence of clay concentration, residue $\mathrm{C} / \mathrm{N}$ and particle size on microbial activity and nutrient availability in clayamended sandy soil. J. Soil Sci. Plant Nutr. 16(2): 350-361.

Salazar-Parra, C., Aranjuelo, I., Pascual, I., Erice, G., Sanz-Sáez, A., Aguirreolea, J., Sánchez-Díaz, M., Irigoyen, J.J., Araus, J.L., Morales, F. 2015. Carbon balance, partitioning and photosynthetic acclimation in fruit-bearing grapevine (Vitis vinifera L. cv. Tempranillo) grown under simulated climate change (elevated $\mathrm{CO}_{2}$, elevated temperature and moderate drought) scenarios in temperature gradient greenhouses. J. Plant Physiol. 174, 97-109.

Salisbury, F.B., Ross, C.W. 1992. Plant Physiol. 4th Edition. Wadsworth Publishing Company, USA.

Shange, L.P., Conradie, W.J. 2012. Effects of soil parent material and climate on the performance of $\mathrm{Vi}$ tis vinifera L. cvs. Sauvignon blanc and Cabernet Sauvignon - Part II. Climate, Leaf Analysis, Juice Analysis and Wine Quality. S. Afr. J. Enol. Vitic. 33(2), 174-183.
Thiec, D.L., Dixon, M., Loosveldt, P., Garrec, J.P. 1995. Seasonal and annual variations of phosphorus, calcium, potassium and manganese contents in different cross-sections of Picea abies (L.) Karst. needles and Quercus rubra L. leaves exposed to elevated $\mathrm{CO}_{2}$. Trees. 10, 55-62.

van Leeuwen, C., Friant, Ph., Choné, X., Trégoat, O., Koundouras, S., Dubourdieu, D. 2004. Influence of climate, soil and cultivar on terroir. Am. J. Enol. Vitic. 55, 207-217.

Wang, R.Z., Cheng, L., Bai, Y.G., Xiao, C.W., 2008. Seasonal dynamics in resource partitioning to growth and storage in response to drought in a perennial rhizomatous grass, Leymus chinensis. J. Plant Growth Regul. 27, 39-48.

Zhu, C., Ziska, L., Zhu, J., Zeng, Q., Xie, Z., Tang, H., Jia, X., Hasegawa, T. 2012. The temporal and species dynamics of photosynthetic acclimation in flag leaves of rice (Oryza sativa) and wheat (Triticum aestivum) under elevated carbon dioxide. Physiol. Plant. 145, 395-405. 